\title{
Synthesis, Structural Analysis and Antimicrobial Screening of Mn(II) Complexes of Schiff Bases
}

\author{
V. Gomathi*, R. Selvameena \\ PG and Research Department of Chemistry, Seethalakshmi Ramaswami College, Tiruchirappalli-620 002, \\ Tamil Nadu, India.
}

*Corresponding author: V. Gomathi, email: vemathi@gmail.com

Received July $3^{\text {st }}, 2021$; Accepted November $18^{\text {th }}, 2021$.

DOI: http://dx.doi.org/10.29356/jmcs.v66i1.1621

\begin{abstract}
Mn}(\mathrm{II})$ complexes of Schiff bases 4-((3-ethoxy-2-hydroxybenzylidene)amino)-N-(pyridin-2yl)benzenesulfonamide $\quad\left(\mathrm{HL}_{2}\right)$ and 4-((3-ethoxy-2-hydroxybenzylidene)amino)-N-(pyrimidin-2yl)benzenesulfonamide $\left(\mathrm{HL}_{3}\right)$ were synthesized. The Schiff bases $\mathrm{HL}_{2}$ and $\mathrm{HL}_{3}$ and their complexes were characterized by analytical, conductance, magnetic susceptibility measurements, infrared, ultraviolet-visible, thermal analysis, and EI mass techniques. The spectral data of the complexes have revealed the bidentate complexing nature of the Schiff base ligand through phenoxide ion and azomethine nitrogen atoms. The antibacterial activities of complexes were tested against gram-positive bacterial species Pseudomonas aeruginosa (NCIM 2036) and fungal species Aspergillus niger (NCIM 105) and Mucor sp. (NCIM 108) by disc diffusion method.
\end{abstract}

Keywords: Schiff bases; Mn(II) complex; antibacterial; antifungal.

Resumen. Los complejos de Mn(II) de las bases de Schiff 4-((3-etoxi-2-hidroxibencilideno)amino)-N-(piridin2-il)bencenosulfonamida $\quad\left(\mathrm{HL}_{2}\right) \quad$ y $\quad 4$-((3-etoxi-2-hidroxibencilideno)amino)-N-(pirimidin-2il)bencenosulfonamida $\left(\mathrm{HL}_{3}\right)$ fueron sintetizados. Las bases de Schiff $\mathrm{HL}_{2}$ and $\mathrm{HL}_{3}$ y sus complejos fueron caracterizados por métodos analíticos, conductancia, susceptibilidad magnética, espectroscopia infrarroja y UV-vis, termogravimetría, y espectrometría de masas por impacto enectrónico. Los datos espectroscópicos obtenidos para los complejos corroboraron la coordinación bidentada de los ligantes de base de Schiff a través del ion fenóxido y el átomo de nitrógeno del grupo azometino. La actividad antibacterial de los complejos se evaluó contra cepas bacterianas gram-positivas Pseudomonas aeruginosa (NCIM 2036) y contra especies fúngicas Aspergillus niger (NCIM 105) y Mucor sp. (NCIM 108) utilizando el método de difusión en disco.

Palabras clave: Bases de Schiff; complejo de Mn(II); antibacterial; antifúngico.

\section{Introduction}

Sulfa drugs were the first drug largely employed and systematically used as preventive and chemotherapeutic agents against various diseases [1]. The sulfa drugs are well known for their biological activity. They are active against a broad range of gram positive and gram-negative bacteria and function antagonists to bacterial folate synthesis [2]. The synthesis of transition metal complexes with Schiff base ligands are studied due to strong ability to form complexes, sensitivity, selectivity and synthetic flexibility towards metal atoms [3,4]. Schiff bases and their metal complexes exhibit biological activities as antibiotics, antiviral and antitumour agents 
because of their specific structure [5,6]. The complexes showed enhanced antimicrobial activity as compared to uncomplexed Schiff base [7-11]. In light of these, we become interested and in continuation of our research work $[12,13]$ the complexes synthesized from 4-((2-hydroxynaphthalen-1-ylmethylene)amino)-N-(pyridin-2yl) benzenesulfonamide $\left(\mathrm{HL}_{1}\right)$ [14] in the present paper we report the synthesis, characterization and antimicrobial activity of $\mathrm{Mn}(\mathrm{II})$ complexes of Schiff bases 4-((3-ethoxy-2-hydroxybenzylidene) amino)-N(pyridin-2-yl)benzenesulfonamide $\left(\mathrm{HL}_{2}\right)$ and 4-((3-ethoxy-2-hydroxybenzylidene)amino)-N-(pyrimidin-2yl)benzenesulfonamide $\left(\mathrm{HL}_{3}\right)$.

\section{Experimental}

\section{Materials and Methods}

The Manganese(II) acetate tetrahydrate $-\mathrm{Mn}\left(\mathrm{CH}_{3} \mathrm{COO}\right)_{2} \bullet 4 \mathrm{H}_{2} \mathrm{O}$ and solvents were purchased from Merck and used as such as. The ligands $\mathrm{HL}_{2}$ and $\mathrm{HL}_{3}$ were used in this study were synthesized by the same authors in PG and Research Department of Chemistry of Seethalakshmi Ramaswami College, Tiruchirappalli, India; details of the procedure described in the journal [12-14].

The conductance of the complexes in N,N dimethylformamide (DMF) $\left(10^{-3} \mathrm{M}\right)$ solutions were measured at $298 \mathrm{~K}$ in a Elico conductivity bridge and dip type conductivity cell with cell constant $1.0 \mathrm{~cm}^{-1}$. The IR spectra of ligands and their complexes were recorded in $\mathrm{KBr}$ pellets in the $4000-400 \mathrm{~cm}^{-1}$ range on Perkin Elmer IR RXI Spectrometer and Shimadzu IR Affinity 1. The electronic spectra were recorded using Perkin Elmer Lambda 35 spectrometer in 190-1100 nm range using dimethyl sulfoxide (DMSO) as solvent. Magnetic susceptibility measurement was performed on powder samples at $298 \mathrm{~K}$ on electromagnet/Gouy method-PICO make using mercury tetrathio cyanatocobaltate (II) as calibrant. Simultaneous TG and DTA patterns of the complexes were recorded on Perkin Elmer STA 6000, Diamond TG/DTA with heating rate $40.00{ }^{\circ} \mathrm{C}$ to $740.00{ }^{\circ} \mathrm{C}$ at $10.00{ }^{\circ} \mathrm{C} / \mathrm{min}$. EI mass spectra were recorded on GC-Mass Spectrometer - Jeol GCMS GC-Mate II make. The photoactive potentiality of the ligand and the complexes were investigated by fluorescence measurements using Perkin Elmer LS 45 Spectrofluorometer. Antimicrobial activity studies were carried out by Disc Diffusion Technique.

\section{Synthesis of Schiff base $\left(\mathrm{HL}_{2} / \mathrm{HL}_{3}\right)$}

To a hot stirred ethanolic solution of sulfapyridine/sulphapyrimidine $(1.245 \mathrm{~g} / 1.2514,0.005 \mathrm{~mol})$ an ethanolic solution of 3ethoxysalicylaldehyde $(0.834 \mathrm{~g}, 0.005 \mathrm{~mol})$ was added. The reaction mixture was refluxed for $3 \mathrm{~h}$. The coloured solid mass formed during refluxing was cooled, filtered, washed thoroughly with ethanol and dried in a desiccator. The compound was purified by recrystallization from ethanol. The purity of the ligand was checked by melting point, TLC and spectral data. $\mathrm{HL}_{2}$ - Yield: $1.7260 \mathrm{~g}$ (83 \%). Colour: Orange; m.p. $185^{\circ} \mathrm{C}$; Elemental Analysis (\%) calculated for $\mathrm{C}_{20} \mathrm{H}_{19} \mathrm{~N}_{3} \mathrm{O}_{4} \mathrm{~S}$ : C 60.45; H 4.79; N 10.58; S 8.06. Found: C 60.01; H 4.12; N 11.48; S 9.02. ${ }^{1} \mathrm{H}$ NMR spectrum: $\delta 8.96 \mathrm{ppm}(\mathrm{s}, 1 \mathrm{H})-\mathrm{CH}=\mathrm{N}, \delta 12.72 \mathrm{ppm}(\mathrm{s}, 1 \mathrm{H})-\mathrm{OH}, \delta$ $6.87-7.95 \mathrm{ppm}(\mathrm{m}, 11 \mathrm{H})$ aromatic, $\delta 1.32-1.36 \mathrm{ppm}(\mathrm{t}, 3 \mathrm{H})-\mathrm{CH}_{3}, 4.04-4.07 \mathrm{ppm}(\mathrm{q}, 2 \mathrm{H})-\mathrm{CH}_{2}$ protons. ${ }^{13} \mathrm{C} \mathrm{NMR}$ spectrum: $\delta 165.35 \mathrm{ppm} \quad-\mathrm{CH}=\mathrm{N}, \delta 150.77 \mathrm{ppm}$ phenolic, $\delta 112.09-147.37 \mathrm{ppm}$ aromatic, $\delta 64.15 \mathrm{ppm}-$ $\mathrm{CH}_{2}, \delta 14.68 \mathrm{ppm}-\mathrm{CH}_{2}$ carbon. EI Mass spectrum: $\mathrm{C}_{20} \mathrm{H}_{19} \mathrm{~N}_{3} \mathrm{O}_{4} \mathrm{~S}: 397.02$ (Calcd., 397). $\mathrm{HL}_{3}$ - Yield: $1.7260 \mathrm{~g}$ (70\%). Colour: Orange; m.p.170。 C; Elemental Analysis (\%) calculated for $\mathrm{C}_{19} \mathrm{H}_{18} \mathrm{~N}_{4} \mathrm{O} \mathrm{O}_{4} \mathrm{~S}: \mathrm{C}$ 57.29; H 4.52; N 14.07; S 8.04. Found: C 57.20; H 4.50; N 14.34; S 8.79. ${ }^{1} \mathrm{H}$ NMR spectrum: $\delta 8.45 \mathrm{ppm}(\mathrm{s}, 1 \mathrm{H})-\mathrm{CH}=\mathrm{N}, \delta$ $12.62 \mathrm{ppm}(\mathrm{s}, 1 \mathrm{H})-\mathrm{OH}, \delta 5.94-7.59 \mathrm{ppm}(\mathrm{m}, 11 \mathrm{H})$ aromatic, $\delta 1.33-1.36 \mathrm{ppm}(\mathrm{t}, 3 \mathrm{H})-\mathrm{CH}_{3}, 4.05-4.01 \mathrm{ppm}$ $(\mathrm{q}, 2 \mathrm{H})-\mathrm{CH}_{2}$ protons. ${ }^{13} \mathrm{C}$ NMR spectrum: $\delta 165.54-\mathrm{CH}=\mathrm{N}, \delta 158.28 \mathrm{ppm}$ phenolic, $\delta 64.12 \mathrm{ppm}-\mathrm{CH}_{2}, \delta$ $14.68 \mathrm{ppm}-\mathrm{CH}_{2}$ carbon. EI Mass spectrum: $\mathrm{C}_{19} \mathrm{H}_{18} \mathrm{~N}_{4} \mathrm{O}_{4} \mathrm{~S}: 398.49$ (Calcd., 398).

\section{Synthesis of Mn (II) complexes}

To a hot magnetically stirred ethanolic solution of Schiff bases 4-((3-ethoxy-2hydroxybenzylidene)amino)-N-(pyridin-2-yl)benzenesulfonamide $\left(\mathrm{HL}_{2}\right) \quad(0.005) \quad / \quad$ 4-((3-ethoxy-2hydroxybenzylidene)amino)-N-(pyrimidin-2-yl)benzenesulfonamide $\left(\mathrm{HL}_{3}\right)(0.005)$ in minimum quantity of dimethyl formamide, an ethanolic solution of the $\mathrm{Mn}(\mathrm{II})$ acetate $(0.0025 \mathrm{~mol})$ was added separately. The 
mixtures were refluxed for $6 \mathrm{~h}$ on a water bath. The brownish yellow and peat brown precipitates formed during refluxing were cooled in an ice bath and collected by suction filtration, washed thoroughly with ethanol and pet ether, dried in desiccator over $\mathrm{CaCl}_{2}$. The coloured solids obtained were partially soluble in ethylene glycol, ethanol, acetic acid, nitromethane \& acetonitrile and soluble in DMF \& DMSO. The synthesis of the complexes $1 \& 2$ is shown in Scheme 1.

$\mathrm{Mn}\left(\mathrm{CH}_{3} \mathrm{COO}\right)_{2} \cdot 4 \mathrm{H}_{2} \mathrm{O}+2 \mathrm{HL}_{2} / \mathrm{HL}_{3}$ ethanol and DMF $\left[\mathrm{Mn}\left(\mathrm{L}_{2}\right)_{2}\right] /\left[\mathrm{Mn}\left(\mathrm{L}_{3}\right)_{2}\left(\mathrm{H}_{2} \mathrm{O}\right)_{2}\right]+2 \mathrm{CH}_{3} \mathrm{COOH}+\mathrm{nH}_{2} \mathrm{O}, \mathrm{n}=4 / 2$

Scheme 1. Synthetic route of $\left[\mathrm{Mn}\left(\mathrm{L}_{2}\right)_{2}\right]$ and $\left[\mathrm{Mn}\left(\mathrm{L}_{3}\right)_{2}\left(\mathrm{H}_{2} \mathrm{O}\right)_{2}\right]$.

\section{Biological assay}

The antimicrobial activity of ligands and their complexes were tested against gram positive bacterial species Pseudomonas aeruginosa (NCIM 2036) and fungal species Aspergillus niger (NCIM 105) and Mucor $s p$. (NCIM 108) by disc diffusion method. The test was carried out in DMSO solution at a concentration of 100 ppm. The results were compared with standard drugs Ciprofloxacin for bacteria and Nystatin for fungi at the same concentration.

\section{Results and Discussion}

The physical characteristics of the Schiff bases and their complex are given in Table 1.

Table 1. Physical characteristics and analytical data of metal complexes.

\begin{tabular}{|c|c|c|c|c|c|c|c|c|c|}
\hline \multirow{2}{*}{$\begin{array}{c}\text { S. } \\
\text { No. }\end{array}$} & \multirow{2}{*}{$\begin{array}{c}\text { Metal Complexes } \\
\text { Folecular }\end{array}$} & \multirow{2}{*}{$\begin{array}{c}\text { Yield } \\
\text { Formula }\end{array}$} & $\mathbf{\%}$ & $\begin{array}{c}\mathbf{M} \text {. } \\
\mathbf{P t}{ }^{\circ} \mathbf{C}\end{array}$ & $\mathbf{C}$ & $\mathbf{H}$ & $\mathbf{N}$ & $\mathbf{S}$ & Mn \\
\hline 1 & {$\left[\mathrm{Mn}\left(\mathrm{L}_{2}\right)_{2}\right]$} & $\mathrm{MnC}_{40} \mathrm{H}_{36} \mathrm{~N}_{6} \mathrm{O}_{8} \mathrm{~S}_{2}$ & 64 & 268 & $\begin{array}{c}56.55 \\
(56.68)\end{array}$ & $\begin{array}{c}4.18 \\
(4.25)\end{array}$ & $\begin{array}{c}9.56 \\
(9.92)\end{array}$ & $\begin{array}{c}7.51 \\
(7.60)\end{array}$ & $\begin{array}{c}6.33 \\
(6.49)\end{array}$ \\
\hline 2 & {$\left[\mathrm{Mn}\left(\mathrm{L}_{3}\right)_{2}\left(\mathrm{H}_{2} \mathrm{O}\right)_{2}\right]$} & $\mathrm{MnC}_{38} \mathrm{H}_{38} \mathrm{~N}_{8} \mathrm{O}_{10} \mathrm{~S}_{2}$ & 64 & 240 & $\begin{array}{c}51.20 \\
(51.52)\end{array}$ & $\begin{array}{c}4.11 \\
(4.29)\end{array}$ & $\begin{array}{c}12.08 \\
(12.66)\end{array}$ & $\begin{array}{c}7.08 \\
(7.23)\end{array}$ & $\begin{array}{c}6.10 \\
(6.21)\end{array}$ \\
\hline
\end{tabular}

\section{Analytical data}

The analytical data obtained for the Schiff bases and their complexes agree very well with the proposed molecular formulae and also indicates the formation of 1:2 metal and ligand ratio in the complexes. The theoretical values are in good agreement with the experimental values of $\%$ of elements $\mathrm{C}, \mathrm{H}, \mathrm{N}, \mathrm{S}$ and the metal (Table 1). The colour of the complexes are attributed due to d-d transition because of unpaired electron in the $\mathrm{d}$ orbital. The sharp and high melting point of the complexes propose the formation of chelate.

\section{Conductance}

The molar conductance of metal complexes is measured using $10^{-3} \mathrm{M}$ DMF solutions and are found 12.00 and $13.50 \mathrm{ohm}^{-1} \mathrm{~cm}^{2} \mathrm{~mol}^{-1}$ for the complexes 1 and $\mathbf{2}$ suggesting the non-electrolytic nature [15-18] and indicate that no anions are present outside the coordination sphere.

\section{IR Spectra}

A sharp band at 1627 and $1616 \mathrm{~cm}^{-1}$ are assignable to the azomethine [19-22] $v(-\mathrm{CH}=\mathrm{N})$ present in the Schiff bases $\mathrm{HL}_{2}$ and $\mathrm{HL}_{3}$. Evidence of nitrogen bonding of the azomethine $v(-\mathrm{CH}=\mathrm{N})$ group to the central metal atom stems from the shift of the frequency to 1610 and $1598 \mathrm{~cm}^{-1}$ in the complexes $\mathbf{1}$ and $\mathbf{2}$. This is further supported by the appearance of the new bands at 445 and $435 \mathrm{~cm}^{-1}$ due to $v(\mathrm{Mn}-\mathrm{N})$ band $[23,24]$. A broad band 
centered at 3433 [25] and $3356 \mathrm{~cm}^{-1}$ is characteristic of hydrogen bonded phenolic $v(\mathrm{O}-\mathrm{H})$ stretching vibration of $\mathrm{HL}_{2}$ and $\mathrm{HL}_{3}[26]$. The coordination through phenolic oxygen, after deprotonation is revealed by the disappearance of the band at 3433 and $3356 \mathrm{~cm}^{-1}$ in the complexes 1 and 2 and it is further confirmed by the appearance of the non-ligand bands at 540 and $544 \mathrm{~cm}^{-1}$ due to $v(\mathrm{Mn}-\mathrm{O})$ in the complexes [27]. The bands at $1358 \mathrm{~cm}^{-1} \& 1327 \mathrm{~cm}^{-1}$ and $1133 \mathrm{~cm}^{-1} \& 1157 \mathrm{~cm}^{-1}$ are assigned to $v_{\text {as }}\left(\mathrm{SO}_{2}\right)$ and $v_{\mathrm{s}}\left(\mathrm{SO}_{2}\right)$ remains almost at the same position in the complexes suggesting that the sulfonamide oxygen of $\mathrm{HL}_{2}$ and $\mathrm{HL}_{3}$ is not taking part in coordination [28,29]. The $v(\mathrm{~N}-\mathrm{H})$ mode of the sulphonamide group of $\mathrm{HL}_{2}$ and $\mathrm{HL}_{3}$ is observed at 2924 and $2927 \mathrm{~cm}^{-1}$, remain unperturbed in the spectra of its complexes suggests that the sulphonamide nitrogen is not taking part in coordination. The band due to $v(-\mathrm{N}=)$ of pyridine and pyrimidine ring appearing at 1589 and 1581 $\mathrm{cm}^{-1}$ did not show any appreciable change on complexation prove that ring nitrogen not involved in coordination.

\section{Electronic spectra and magnetic susceptibility measurements}

The electronic spectrum of complex 1 (Fig. 1) shows band at $411 \mathrm{~nm}\left(24330 \mathrm{~cm}^{-1}\right)$ due to ${ }^{4} \mathrm{~A}_{1} \rightarrow{ }^{4} \mathrm{~T}_{1}$ transition [30], exhibits paramagnestism with magnetic moment value of 5.61 B.M. suggesting tetrahedral geometry. The complex 2 (Fig. 2) exhibit weak band at $476 \mathrm{~nm}\left(21008 \mathrm{~cm}^{-1}\right)$ which is assigned to ${ }^{6} \mathrm{~A}_{1 \mathrm{~g}} \rightarrow{ }^{4} \mathrm{~T}_{2 \mathrm{~g}}(\mathrm{G})$ transition [31,32]. This observation reveals that the stereochemistry of complex 2 is consistent with the sixcoordinate octahedral geometry. It exhibits magnetic moment value of 5.94 B.M. [33] suggesting octahedral geometry.

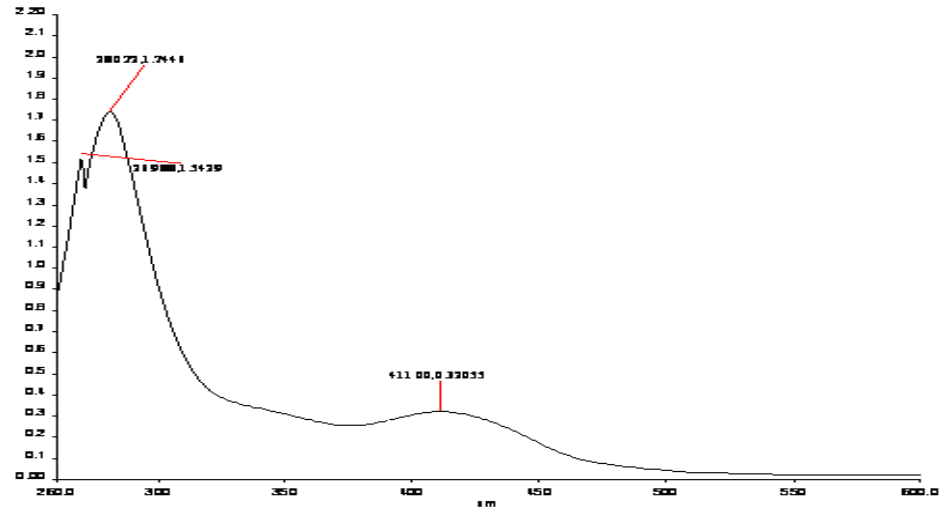

Instrument Model Arithmetic

Fig. 1. UV spectrum of complex 1.

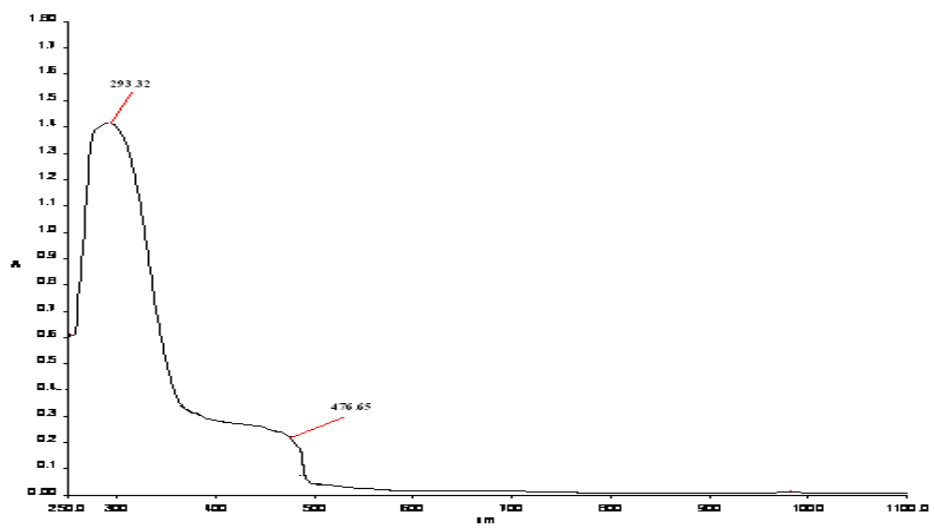

Instrument Model Arithmetic

Fig. 2. UV spectrum of complex 2. 


\section{Thermal analysis}

The thermogram of complex 1 (Fig. 3) has no endothermic peak in the range of $60-250{ }^{\circ} \mathrm{C}$. This excludes the possibility of lattice or coordinated water molecules in this complex [34] and supports the four coordination and tetrahedral geometry around Mn (II) ion.

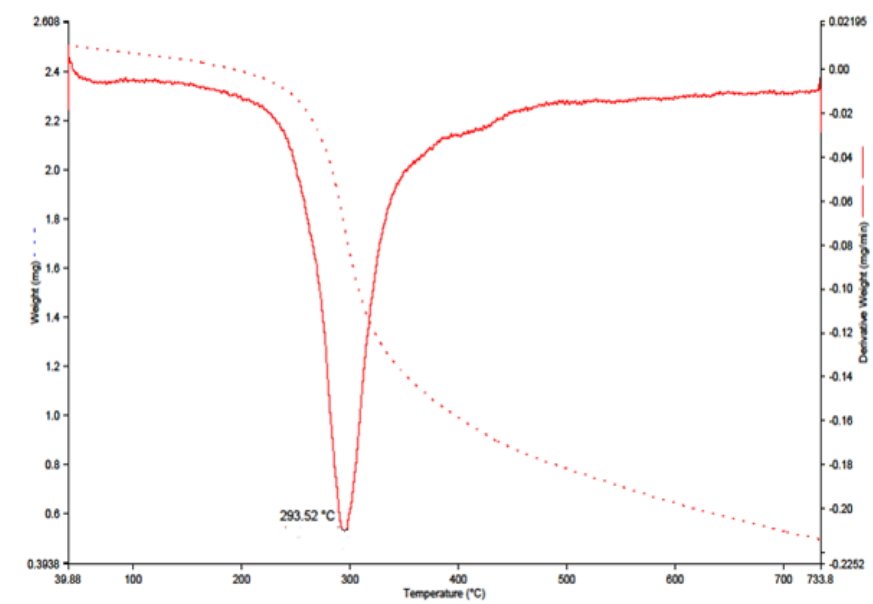

Fig. 3. Thermogram of complex 1.

The thermogram of complex 2 (Fig. 4) shows weight loss of $4.0 \%$ (Calcd., $4.03 \%$ ) in the temperature $234{ }^{\circ} \mathrm{C}$ attributed to the loss of two coordinated water molecules. This thermogram supports the octahedral geometry for complex 2 .

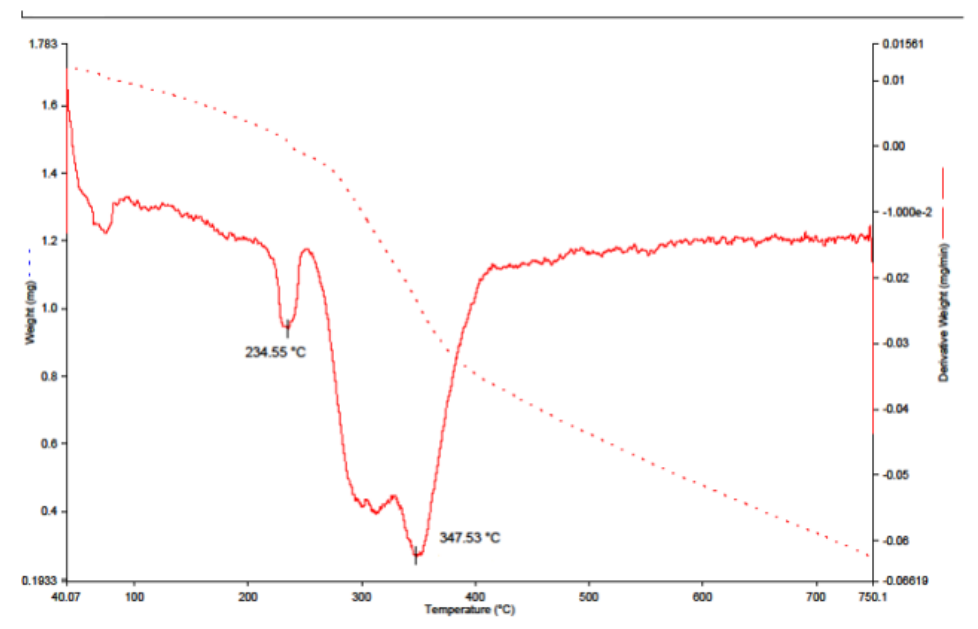

Fig. 4. Thermogram of complex 2.

\section{EI Mass Spectra}

The mass spectral data of all the complexes (Fig. 5 and 6) are consistent with the formulations: $\mathrm{MnC}_{40} \mathrm{H}_{36} \mathrm{~N}_{6} \mathrm{O}_{8} \mathrm{~S}_{2}: 847.13$ (Calcd., 846.94) and $\mathrm{MnC}_{38} \mathrm{H}_{38} \mathrm{~N}_{8} \mathrm{O}_{10} \mathrm{~S}_{2}: 884.93$ (Calcd., 884.94). 


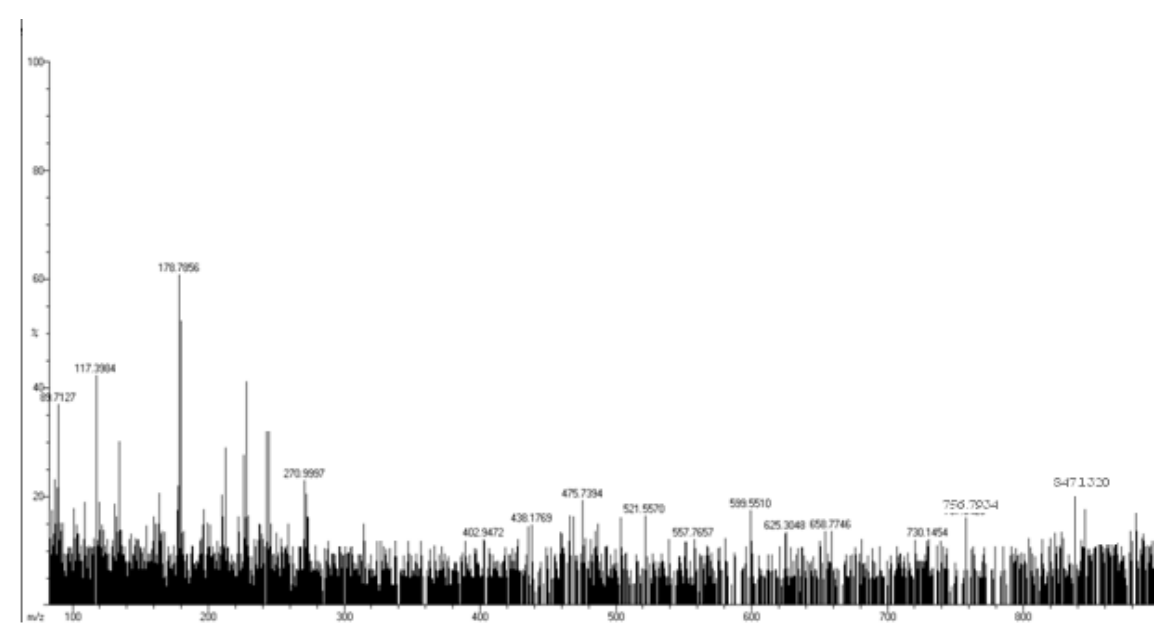

Fig. 5. EI Mass spectrum of complex 1.

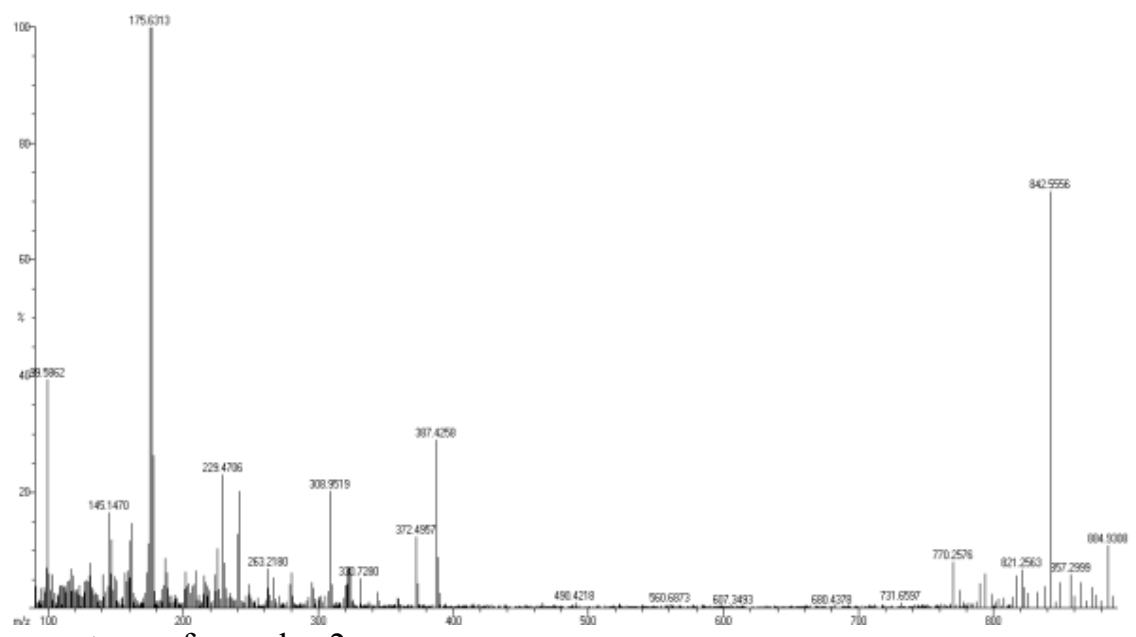

Fig. 6. EI Mass spectrum of complex 2.

Based on the analytical data, molar conductance value, newly formed band around 400 and $500 \mathrm{~cm}^{-1}$ in IR spectra illustrate non-electrolytic, 1:2 metal to ligand ratio and coordinate covalent nature of bond respectively. The absorption band at 24330 and $21008 \mathrm{~cm}^{-1}$, magnetic moment value and the thermogram of complexes prove the presence of LMCT transitions and tetrahedral arrangement for complex 1 and octahedral environment for complex 2. The above data confirmed that the Schiff bases act as bidentate monobasic ligand and coordination is proposed through azomethine nitrogen and oxygen of phenoxide ion and the following structures have been proposed for the newly synthesized complexes $\mathbf{1}$ and $\mathbf{2}$. 
(1)

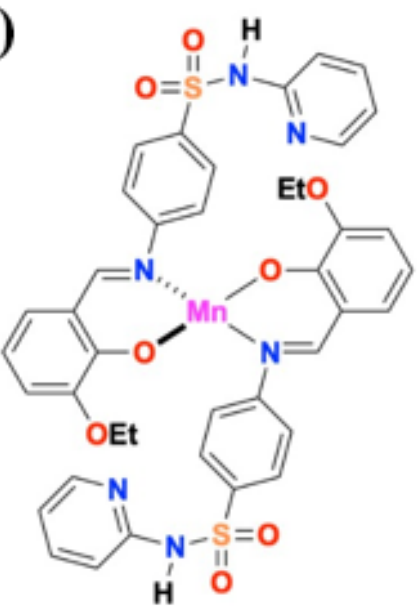

(2)

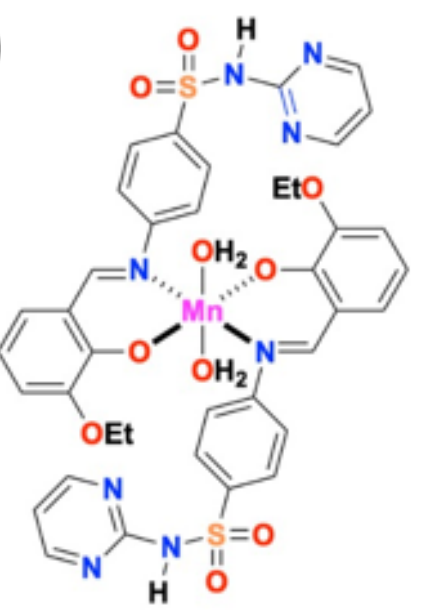

Scheme 2. (1) Proposed structure of $\left[\mathrm{Mn}\left(\mathrm{L}_{2}\right)_{2}\right]$, (2) Proposed structure of $\left[\mathrm{Mn}\left(\mathrm{L}_{3}\right)_{2}\left(\mathrm{H}_{2} \mathrm{O}\right)_{2}\right]$.

\section{Antimicrobial Assessment.}

Both the Schiff bases and the complexes produced different diameter of inhibition zones was detected in millimeter against the tested microorganisms. The zone of inhibition of the complexes against the growth of bacteria and fungi are shown in Fig. 7 and 8. The comparative study of $\mathrm{HL}_{2}, \mathrm{HL}_{3}$ and its metal complexes indicates that the Schiff bases have been found to be biologically active and its metal complexes possess enhanced antimicrobial activities. The complex $\mathbf{1}$ bio potency has been much pronounced compared to the free Schiff base $\mathrm{HL}_{2}$ [35-38]. The enhanced activity of the complexes can be explained on the basis of Overtone's concept [39] and Tweedy's Chelation theory [40]. The Overtone's concept of cell permeability states that the cell membrane surrounding the microbial cell favours the passage of lipid soluble particles causing lipid solubility to be a crucial factor in determining antimicrobial activity and chelation tends to reduce the polarity of the metal ion due to the overlap of the ligand orbital and partial sharing of positive charge with the donor groups which results in rise in the lipophilicity of the metal complex [41]. So, the metal complex can easily penetrate into the lipid membranes and block the metal binding sites of enzymes of the microorganisms and block the synthesis of proteins, which limit further growth of the organism $[42,43]$.
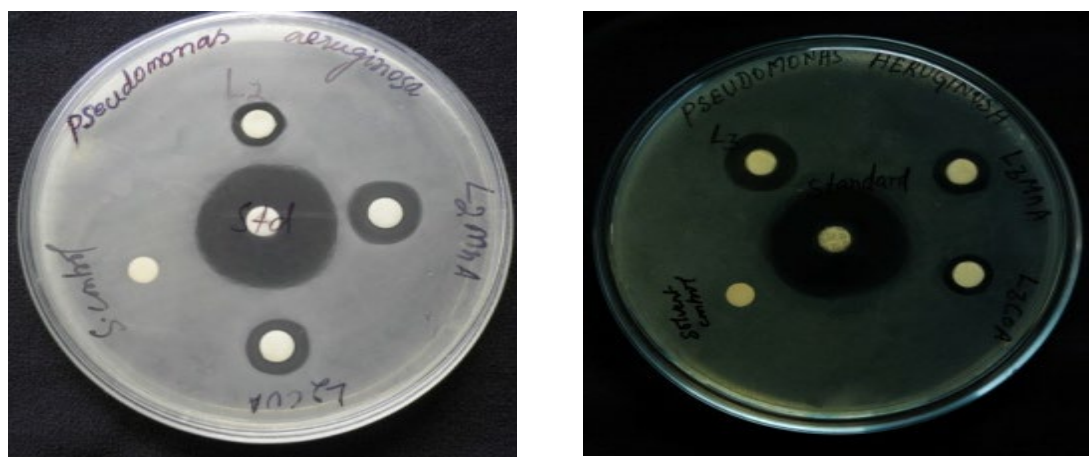

Fig. 7. In vitro antibacterial screening of Schiff bases and their metal complex against Pseudomonas aeruginosa. 


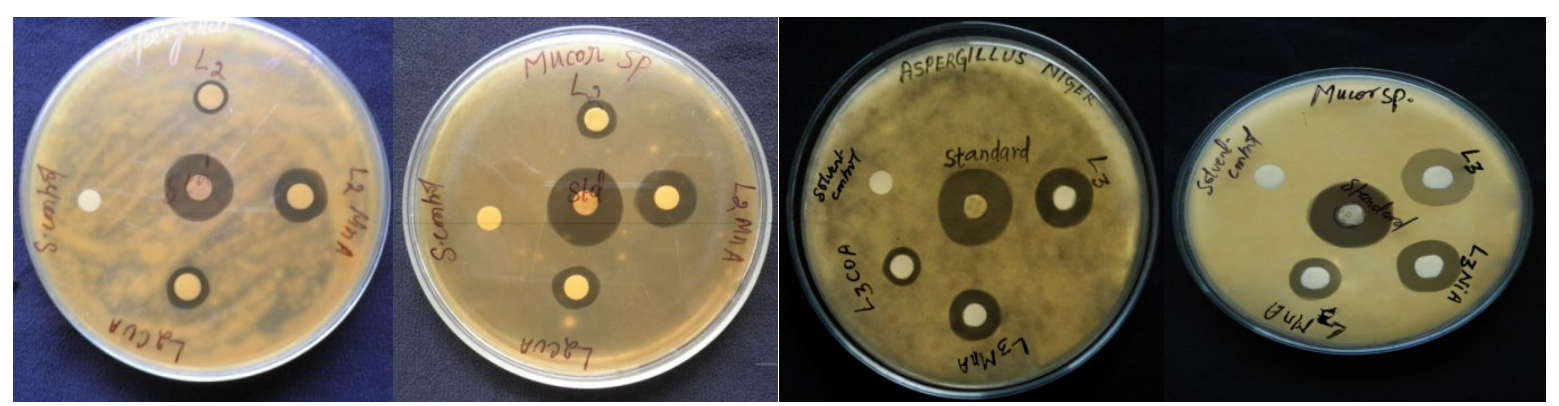

Fig. 8. In vitro antifungal screening of Schiff bases and their metal complex against Aspergillus niger and Mucor $s p$.

\section{Conclusion}

Based on the above physical and chemical studies it is concluded that the Schiff bases act as bidentate monobasic ligand and coordination is proposed through azomethine nitrogen and oxygen of phenoxide ion. Based on the spectral data tetrahedral structure has been assigned to complex $\mathbf{1}$ and octahedral structure has been assigned to the complex 2 . The ligand $\mathrm{HL}_{2}$ and complexes show significant activity. The antimicrobial activity is enhanced for $\left[\mathrm{Mn}\left(\mathrm{L}_{2}\right)_{2}\right]$ when compared to Schiff base.

\section{Acknowledgement}

The authors are thankful to the Secretary, Seethalakshmi Ramaswami College, for providing necessary infrastructure and facility and the timely help provided by the faculty members, PG and Research Department of Chemistry, Seethalakshmi Ramaswami College, Tiruchirappalli-620 002, Tamil Nadu, India.

\section{References}

1. C. Hansch, G.; Sammes, J. ; Taylor, B. Comprehensive Medicinal Chemistry, Pergamon Press: Oxford 2. Chapter 7.1, 1990.

2. Vree, T. H. Clinical Pharmacokinetics of sulfonamides and their metabolities. Karger Basel 1987, 37.

3. Spinu, C.; Kriza, A. Acta Chim. 2000, 47, 179-185.

4. Qu, Y.; Wang, C.; Wu, Y. C.; Zhao, K.; Wu, H. L. J. Appl. Spectrosc. 2000, 87, 429-436.

5. Ramesh, M.; Chandrasekhar, K.B.; Reddy Hussain, K. Indian J. Chem A. 2000, 39, 1337-1339.

6. Kaczmarek, M. T.; Jastrząb, R.; Hołderna-Kędzia, E.; Radecka-Paryzek, W. Inorg. Chim. Acta. 2009, $362,3127-3133$.

7. Gomathi, V.; Selvameena, R.; Subbalakshmi, R.; Valarmathy, G. OJC. 2013, 29, 533-538.

8. Gull, P.; Hashmi, A. A. J. Braz. Chem. Soc. 2015, 26, 1331-1337.

9. Valarmathy, G.; Subbalakshmi, R.; Selvameena, R.; Gomathi, V. OJC. 2012, 29, 315-320.

10. Rama, I.; Usha, V. Asian J. Chem. 2013, 25, 3225-3228.

11. Ramakrishna Reddy, K.; Madhusudan, K. N.; Reddy, R.; Mahindra, K. Indian J. Chem Sec A. 2006, 45, 377-380.

12. Gomathi, V.; Selvameena, R. Main Group Chem. 2013, 12, 275-284.

13. Gomathi, V.; Selvameena, R. Int. J. Sci. Res. 2013, 2, 24-25. 
14. Gomathi, V.; Selvameena, R. Asian J. Chem. 2013, 25, 2083-2086

15. Selma, Y. Russ J Gen Chem. 2014, 84, 1819-1222.

16. Ferro, J. R. Low frequency vibrations of inorganic and coordination compound, New York, John Wiley, 1971.

17. Maurya, R. C.; Chourasia, J.; Sharma, P. Indian J. Chem. 2007, 46, 1594-1604,

18. Maurya, R. C.; Pandey, A.; Sutradhar, D. Indian J. Chem. 2004, 46, 763-769.

19. Kavitha, S.; Singh, D. P. Vikas, K. Indian J. Chem Techn. 2017, 24, 534-537.

20. Halli, M. B.; Vijalaxmi, B. P. Indian J. Chem A. 2011, 50, 664- 668.

21. Safyah Bakare, B. Polish J. Chem. 2019, 21, 26-34.

22. Bodhaei, M. D.; Mohebi, S. J. Chem. Res. 2001, 224-228.

23. Matin, S. J.; Khojasteh, R. R. Russ J. Gen. Chem. 2015, 85, 1763- 1768.

24. Razieh A.; Mohammad Azarkishv.; Tahereh, S. J. Mex. Chem. Soc. 2014, 58, 173-179.

25. Vidyavati, R.; Nirdosh, P.; Angadi, S. D. E- J. Chem. 2008, 5, 577-583.

26. Maurya, R. C.; Chourasia, J. ; Rajak, D.; Malik, B. A.; Mir, J. M.; Jain, N.; Batalia, S. Arabian J. Chem. 2016, 9, S1084-1089.

27. Lu, K. H.; Kia, Q. H.; Zhan, H. J.; Yuan, H. X.; Ye, C. P.; Su, K. X.; Xu, G.; J. Mol. Catal. A: Chem. 2006, 250, 62-69

28. Karthikeyan, G.; Mohanraj, K.; Elango, K.P.; Girishkumar, K. Russ. J. Coord. Chem. 2006, 32, 380385.

29. Selvam, P.; Chandramohan, M.; Clercq, E.D.; Myriam, W.; Christophe, P. Eur. J. Pharm. Sci. 2001, 14, 313-318.

30. Raman, N.; Raja. S. J.; Sakthivel, A. J. Coord. Chem. 2009, 62, 691-709.

31. Lever, A.B.P., “In Inorganic Electronic Spectroscopy”, 2 $2^{\text {nd }}$ ed, Elsevier, Amsterdam, 1984, 449.

32. Philip, V.; Suni, V.; Prathapchandra Kurup, M. R. P.; Nethaji, M. Spectrochim. Acta A. 2006, 64, 171178.

33. Batra, G.; Mathur, P. Transit. Metal Chem. 1994, 19, 160-165.

34. Sulekh, C.; Savitha, B.; Rita, N.; Kushal, Q.; Saroj, K.; Sharma, K.; Spectrochim. Acta A., 2013, 113, 16-23.

35. Li, F.; Feterl, M.; Mulayana, Y.; Warner, J. M.; Collins, J. G.;Keene, F. R. J. Antimicrob. Chemother. 2012, 67, 2686-2695.

36. Sharaby, C. M. Spectrochim. Acta A, 2007, 66, 1271-1278.

37. Naeimi, H.; J. Antimicrob. Chemother Moradian, M. J. Coord Chem. 2010, 63, 450-456.

38. Revanasiddappa, M.; Suresh, T.; Khasim, S.; Raghavendray, S. C.; Basavaraja, C.; Angadi, S. D. EJ. Chem. 2008, 5, 395-403.

39. Anjaneyulu, Y.; Rao, P. R. Synth. React. Inorg. Met.-Org. Chem. 1986, 16, 257-261.

40. Dharmaraj, N.; Viswanathamurthi, P. Natarajan, K. Transit. Matal Chem. 2007, 26, 105.

41. Mahajan, K.; Fahmi, N.; Singh, R. V. Indian J. Chem. 2007, 46, 1221-1225.

42. El-Sherif, A. A.; Eldebss, T. M. A.; Spectrochim. Acta A. 2011, 79, 1803-1814.

43. Bagihalli, G. B.; Avaji, P. G.; Patil, S. A.; Badami, P. S. Eur. J. Med. Chem. 2008, 43, 2639-2649. 